\title{
Chondrolipoma Arising in the Floor of the Mouth and Review of the Literature: A Case Report
}

\author{
Nagamani Narayana ${ }^{\mathrm{a}, \mathrm{c}}$, Brent Henriksen ${ }^{\mathrm{b}}$, John Casey ${ }^{\mathrm{a}}$
}

\begin{abstract}
Only 14 cases of chondrolipoma, a benign mesenchymal tumor containing mature cartilage and adipose tissue, have been reported from the oral cavity with tongue as the most common location. This case report describes a 56-year-old male with an asymptomatic mass in the floor of the mouth, which had doubled in size during the previous 6 months. This report is the first reported case of chondrolipoma arising in the floor of the mouth.
\end{abstract}

Keywords: Chondrolipoma; Floor of the mouth; Benign mesenchymal tumor

\section{Introduction}

Lipoma, a benign mesenchymal tumor, occurs commonly on the trunk and extremities and infrequently in the oral cavity, presenting as soft, nodular masses in the buccal mucosa, buccal vestibule, tongue and floor of the mouth in both sexes with a median age of 40 years [1].

Rarely, lipomas containing cartilage have been reported in the tongue and lip [2]. These include chondrolipoma and chondroid lipoma. Chondrolipomas are defined as benign tumors containing mature cartilage and adipose tissue while chondroid lipoma contains immature cartilage. We report a chondrolipoma occurring in the anterior floor of the mouth, a site not previously described.

Manuscript accepted for publication February 18, 2014

${ }^{\mathrm{a} D}$ Department of Oral Biology, UNMC, College of Dentistry, 40th and Holdrege Street, Lincoln, NE 68583, USA

${ }^{b} 1700$ S Southeastern Ave, Sioux Falls, SD 57103, USA

${ }^{\mathrm{c}}$ Corresponding author: Nagamani Narayana, Department of Oral

Biology, UNMC, College of Dentistry, 40th and Holdrege Street,

Lincoln, NE 68583, USA. Email: nnarayana@unmc.edu

doi: http://dx.doi.org/10.14740/jmc1714w

\section{Case Report}

A 56-year-old Caucasian male presented with an asymptomatic mass in the floor of the mouth, which had doubled in size during the previous 6 months. Past medical history was positive for hypothyroidism treated with synthroid. He was a

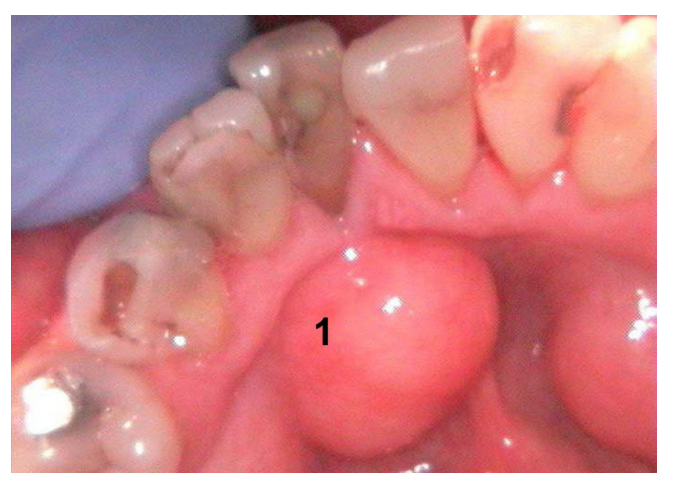

Figure 1. Intraoral photograph showing a well-defined mass (1) in the anterior floor of the mouth.

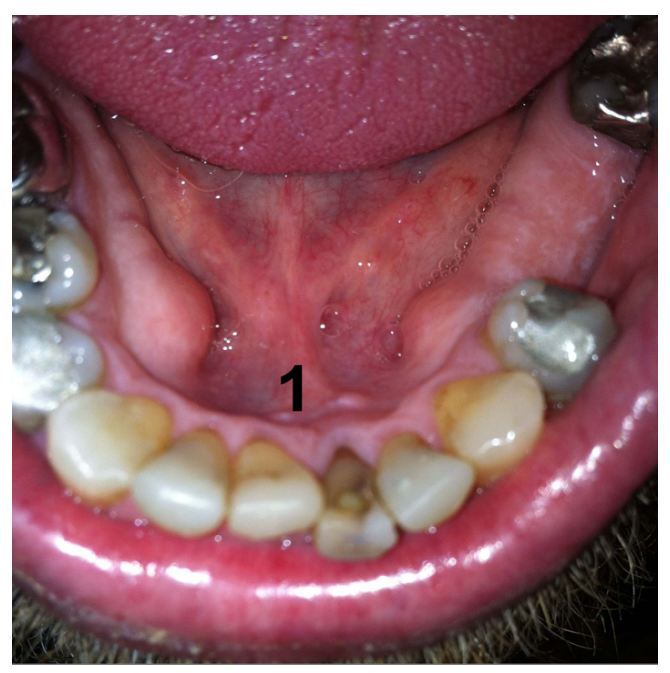

Figure 2. Intraoral photograph demonstrating healing area post excision (1). 


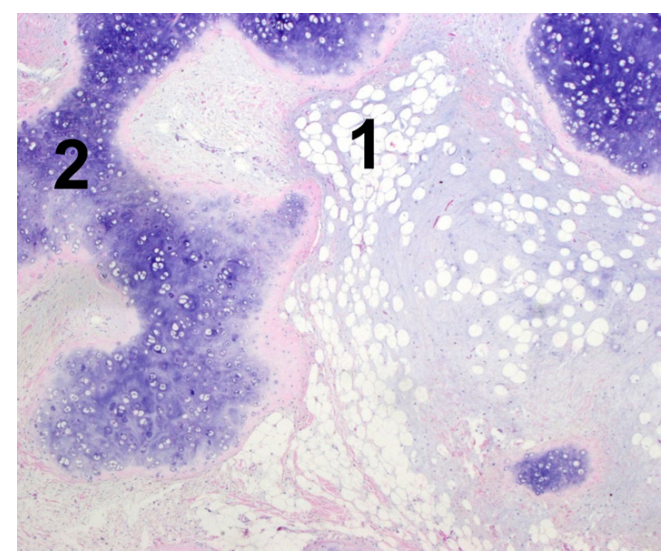

Figure 3. Histology showing lobules of adipose tissue (1) and mature cartilage (2) in a fibrous connective tissue stroma (hematoxilin-eosin stain $\times 2$ ).

half pack-a-day smoker.

On oral examination, a rubbery mass $2.0 \times 1.5 \mathrm{~cm}$ was noted in the anterior floor of the mouth (Fig. 1). Bilateral mandibular tori were also present. The clinical differential diagnosis included dermoid cyst and soft tissue tumors. An excisional biopsy was performed without complication. The area healed uneventfully (Fig. 2).

The tan, soft tissue nodule was $1.5 \times 1.3 \times 1.0 \mathrm{~cm}$ with a glistening, white sectioned surface. Histologically, a well-

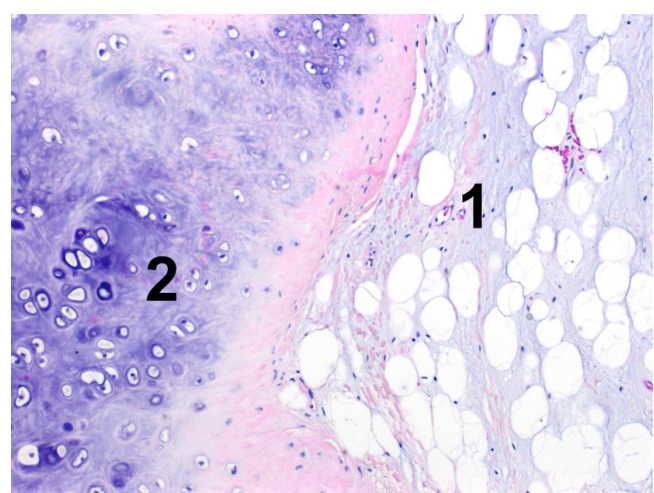

Figure 4. Histology showing lobules of adipose tissue (1) and mature cartilage $(2)$ (hematoxilin-eosin stain $\times 10$ ).

circumscribed benign tumor composed of lobules of mature adipose tissue and mature hyaline cartilage separated by fibrous connective tissue in a fibromyxoid stroma was observed (Fig. 3, 4). The histological features were characteristic of chondrolipoma.

\section{Discussion}

Chondrolipoma is a rare, benign tumor occurring at any age. A literature review of reported chondrolipomas revealed 10

Table 1. Review of Clinical Features of the Reported Cases of Oral Chondrolipomas

\begin{tabular}{llll} 
Author & Location & Gender & Age in years \\
\hline Pitman and Bell [2] & Masseter & Female & 51 \\
Berg and Gorsky [3] & Tongue & Male & 69 \\
Bezerra et al [4] & Tongue & Female & 68 \\
Goel et al [5] & Tongue & Female & 36 \\
Hietnen and Makinen [6] & Tongue & Female & 68 \\
Maes and Eulderink [7] & Tongue & Male & 47 \\
Nonaka et al [8] & Tongue & Male & 30 \\
Shabbir and Greenwood [9] & Tongue & Male & 71 \\
Allard et al [10] & Lower lip & Female & 69 \\
McAndrew and Greenspan [11] & Lower lip & Male & 72 \\
Fujimura and Enomoto [12] & Tongue & Male & 56 \\
Szudrowicz and Jakobi-Roz [13] & Lower lip & Male & 52 \\
Batchvarova et al [14] & Tongue & Male & 14 \\
Current case & Floor of mouth & Male & 56
\end{tabular}


cases in the tongue, three in the lip and one in the masseter [2-14] (Table 1). The present lesion is the first arising in the floor of the mouth. Nine cases including the present case occurred in males with an average age of 51 years. All lesions were excised and without recurrence. One case of chondrolipoma of the tongue in a two year old female is reported in the Spanish literature [8].

The differential diagnosis of floor of the mouth nodules/masses is dependent upon the location and consistency of the lesion. Ranula occurs commonly in the floor of the mouth, less commonly salivary gland tumors, dermoid cysts and mesenchymal tumors. The benign mesenchymal tumors include lipoma, neurofibroma and hemangioma. Dermoid cysts are uncommon true cysts, occurring in the midline of the floor of the mouth.

\section{Conclusion}

An unusual case of chondrolipoma clinically presenting as a red, rubbery mass in the floor of the mouth is reported. The demographics of all cases reported as chondrolipoma from the English literature are presented. The differential diagnosis of nodules/masses in the floor of the mouth is discussed.

\section{Acknowledgement}

Authors would like to thank Dr. Paul Freedman DDS, Oral Pathology Laboratory, INC NY for reviewing the case.

\section{References}

1. Naville B, Damm D, Allen C, Bouquot J, eds. Oral and Maxillofacial Pathology. 3rd ed. 2009.

2. Pitman KT, Bell D. Chondrolipoma of head and neck: case report and review of literature. Head Neck. 2013;35(1):E18-20.

3. Berg T, Gorsky M. Chondrolipoma of the tongue: a case report of a rare diagnosis. Int $\mathrm{J}$ Dermatol. 2010;49(4):441-442.

4. Bezerra MF, Costa FW, Pereira KM, Cavalcante RB, Pouchain EC. Chondrolipoma of the posterior tongue. J Craniofac Surg. 2010;21(6):1982-1984.

5. Goel G, Khadilkar UN, Kumar S. Chondrolipoma of tongue. Kathmandu Univ Med J (KUMJ). 2008;6(24):505-507.

6. Hietanen J, Makinen J. Chondrolipoma of the tongue. A case report. Int J Oral Maxillofac Surg. 1997;26(2):127128.

7. Maes A, Eulderink F. Chondrolipoma of the tongue. Histopathology. 1989;14(6):660-662.

8. Nonaka CF, Miguel MC, de Souza LB, Pinto LP. Chondrolipoma of the tongue: a case report. J Oral Sci. 2009;51(2):313-316.

9. Shabbir F, Greenwood M. Chondrolipoma presenting as a lump on the lateral tongue. Dent Update. 2011;38(3):188-190.

10. Allard RH, Blok P, van der Kwast WA, van der Waal I. Oral lipomas with osseous and chondrous metaplasia; report of two cases. J Oral Pathol. 1982;11(1):18-25.

11. McAndrew PG, Greenspan JS. Lipoma of lip with cartilage formation. Br Dent J. 1976;140(7):239-240.

12. Fujimura N, Enomoto S. Lipoma of the tongue with cartilaginous change: a case report and review of the literature. J Oral Maxillofac Surg. 1992;50(9):1015-1017.

13. Szudrowicz Z, Jakobi-Roz H. Chondrolipoma of the lip. A case report. Pol J Pathol. 1995;46(1):55-56.

14. Batchvarova Z, Kadlub N, Coulomb-L'Hermine A, Picard A, Galliani E. Giant chondrolipoma of the tongue in a 14-year-old child with mandibular hypertrophy. Isolated lesion or regional overgrowth syndrome. Int J Oral Maxillofac Surg. 2012;41(2):261-264. 